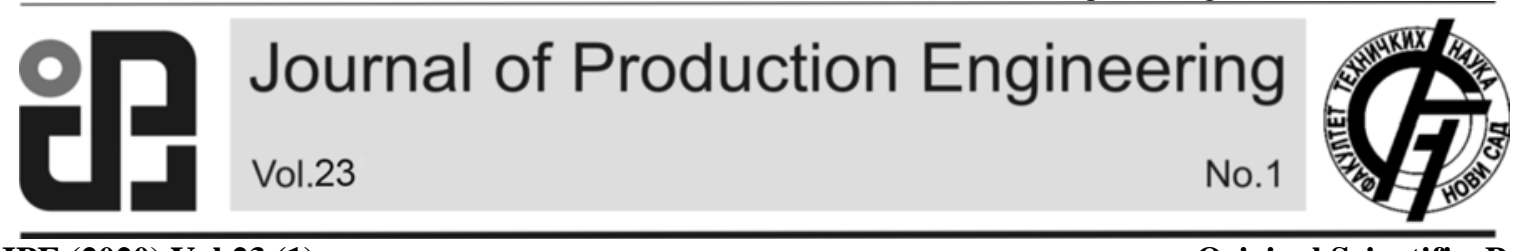

JPE (2020) Vol.23 (1)

Omoniyi, T.E., Onilude, M.A.

Original Scientific Paper

\title{
PRODUCTION ESTIMATION AND DELAY ANALYSES OF A LOCALLY FABRICATED BAND SAW
}

Received: 18 April 2020 / Accepted: 15 June 2020

\begin{abstract}
The objective of the study was to estimate the productivity of a locally fabricated band saw using delay analyses in order to achieve improved production and judicious utilisation of available resources. A time and motion study was applied to collect the data for the processing system and the data recorded and processed. The working cycle of the machine was also recorded and all variables that affect productivity. The result shows productivity was significantly affected by the log supplied characteristics, sawing patterns, maintenance of equipment and level of training. This reveals the need to improve equipment availability and maintenance during sawing.
\end{abstract}

Keywords: Productivity, band saw, delay analyses, working cycle, maintenance.

Procena proizvodnje i analize kašnjenja lokalno proizvedene trakaste testere. Cilj studije bio je proceniti produktivnost lokalno proizvedene trakaste testere koristeći analize kašnjenja kako bi se postigla poboljšana proizvodnja $i$ optimiziralo korišćenje raspoloživih resursa. Za prikupljanje podataka tj. za sistem obrade, primenjena je studija vremena i pokreta, a nakon toga podaci su snimljeni i obrađeni. Takođe je zabeležen radni ciklus mašine i sve varijable koje utiču na produktivnost. Rezultat pokazuje da su na produktivnost značajno uticale karakteristike isporučenih trupca, proces testerisanja, održavanje opreme i nivo obuke. Ovo otkriva potrebu za poboljšanjem dostupnosti i održavanja opreme tokom testerisanja.

Ključne reči: Produktivnost, trakasta testera, analiza kašnjenja, radni ciklus, održavanje.

\section{INTRODUCTION}

Trees play an important ecological role as well as support improved public health and provide aesthetic benefits to the environment. These benefits are well recognised by University of Ibadan that places high premium on trees as living organism and as evolving aspects of the campus life. The University practises responsible tree succession planting that prioritizes tree diversification and ecological sustainability. In line with sustainability approach, matured, aged and hazardous trees that are also available in abundance form wood resource for log and lumbers production. The Institution therefore established a saw mill, which is a facility where logs are converted to lumbers for the purpose of the Sawmill is for teaching and research.

The Sawmill is located at Abadina extension, adjacent to Botanical Garden which is the geographical hub of the wood resource. This was probably done to minimise log haulage costs and to reduce the effect of noise on the academic community because saw milling is a noisy and traditionally labour intensive industry. The expected products from the mill are sawn lumbers of different grades which can further be converted and manufactured into pallets, frames, furniture components, cabinets and building materials. The wastes of the process could also be raw materials for fuel, packaging, cleaning, chemicals and particle boards industries. The Departments of Wood Products Engineering and Forest Production and Products in the University provide suitable platforms for sustainability of the sawmill operations in terms of production and utilisation of the trees.

The sawmill consists of classical one mainframe, single blade, two rotating wheels in the same plane, horizontal band saw with a fixed carriage for the log. The band saw machine is locally fabricated and floormounted and used mainly to convert logs to lumber as shown in Figure 1. The band saw blade is a continuous band of toothed metal stretched between two wheels one of the wheels is powered by an electric motor through a belt and pulley arrangement and the other distribute the load for the blade to be driven and to saw the wood. This mechanism allows the speed of the blades to be adjusted in discrete stages. The objectives of this study are to estimate the capacity, productivity and delays of operations of a locally fabricated sawmill by monitoring the entire sawing processes based on recorded and processed data with the aim of improving the operational efficiency and performance of the mill.

The evaluation of technical efficiency and productivity is now common in many fields with very few interested in forest products related industries [ $1-$ 5]. Related research includes; the evaluation of the factors affecting the productivity and quality of Chain sawing and estimated time taken for using the Chain saw, analyses of various manufacturing delays for tractor production, time and delay for production of forest products, machines and machine efficiency, and the design of a simulation system for sawmill productivity analyses from varying log supply characteristics $[5-15]$. 


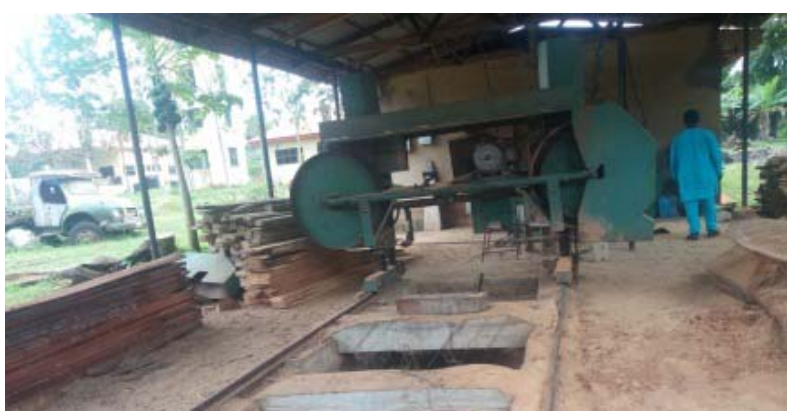

Fig. 1. Locally Fabricated sawmill at University of Ibadan.

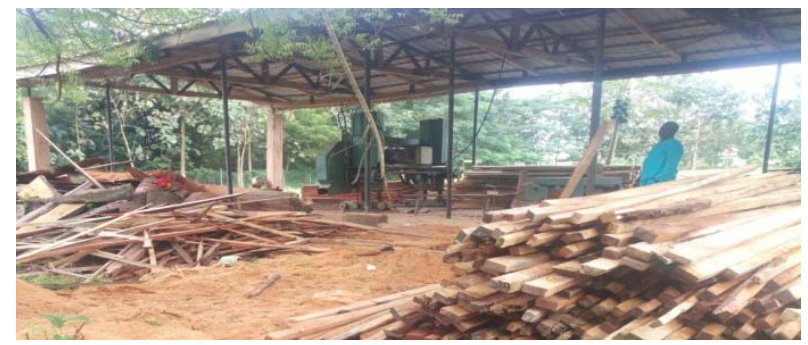

Fig. 2. Lumbers produced at the Sawmill

\section{MATERIALS AND METHODS}

\subsection{Site of Study and Operation}

These researches were conducted through field study at the University of Ibadan, Nigeria which is located on latitude $7^{0} 23^{1} 28.17^{11}$ north and longitude of $3^{0} 54^{1}$ $59.99^{11}$ east. The trees were purposefully selected for harvesting in the University environment and the logs were visually graded. The primary sawmill in which this study was conducted is a locally fabricated sawmill in Abadina part of the campus. The major species sawed in this sawmill are Teak (Tectona grandis), Gmelina (Gmelina arborea), Afara (Terminalia superba), Iroko (Milicia excelsa) and Opepe (Nauclei diderichii). The descriptions of the basic technical features of the locally fabricated log band mill are as presented in Table 1 . Furthermore, the parts of the band mill and their measurements taken are presented in Table 2. The elements (work and time elements) of the band mill are shown in Table 3.

\begin{tabular}{|c|c|}
\hline Description & $\begin{array}{l}\text { The band saw, fabricated locally to saw large, heavy hardwood and softwood logs, } \\
\text { including tropical species. It is minimally durable and easy to use, although requires } \\
\text { more than an operator. The oversize blade wheels reduce stress on the blade and the } \\
\text { long blade length gives longer cutting time between sharpenings. With this band saw, } \\
\text { live sawing is the only type of sawing that can be done efficiently. }\end{array}$ \\
\hline Year of production & 2008 \\
\hline Power unit force & $75 \mathrm{KW}$ \\
\hline Wheel diameter & $962 \mathrm{~mm}$ \\
\hline Speed of saw blade & $30 \mathrm{~m} / \mathrm{s}$ \\
\hline Thickness of saw blade & $1.6 \mathrm{~mm}$ \\
\hline Max. Log Capacity & $\begin{array}{l}\text { Min. Log Diameter (manual bed): 400mm, Max. Log Diameter: 2000mm, Max. Log } \\
\text { Length: } 3700 \mathrm{~mm} \text {, based on rail length, Min. Cut Width: 200mm, Max. Cut Width: } \\
\text { 1000mm. }\end{array}$ \\
\hline Log Handling & Rails: Standard Length: 5m, Rail Extension: $1 \mathrm{~m}$ \\
\hline Power Options & $1.1 \mathrm{~kW}$ Electric, $0.75 \mathrm{~kW}$ Electric, $2 \times 0.25 \mathrm{~kW}$ Electric, \\
\hline Standard & $\begin{array}{l}\text { Blade: Length: 10m, Width: 55mm Blade Wheel: Diameter: } 962 \mathrm{~mm} \text {, Type: Crowned } \\
\text { Steel Dimensions: Head Height: } 3500 \mathrm{~mm} \text {, Head Width: 46`mm, Rail Support: 460mm }\end{array}$ \\
\hline Section & Horizontal band mill Sawmill \\
\hline
\end{tabular}

Table 1. Basic Technical Features of a Locally Fabricated Log Band Mill

Elemental time functions for the band milling which include: loading of log on carriage, moving the headrig and engaging it with the log, and sawing by live method were measured and recorded while the operational variables measured were log and blade parameters, wheels dimensions and motor speed. A total of 200 cycles for band milling were experimented. Log lengths were measured by meter rule while the diameters were measured at top, middle and base and the volume was estimated using standard equations. In addition to the total sawing cycles, the delay times and the reasons for the delays were also recorded. Three categories of delays were used in the delay analysis: personal delay, mechanical delay and operational delay, which represent delays associated with the principle operating functions of the system. The data were analysed using descriptive statistics and ANOVA at $\alpha_{0.05}$.

\begin{tabular}{|l|l|l|}
\hline S/No & Section & Dimension \\
\hline 1 & Blade width & $10 \mathrm{~m}$ \\
\hline 2 & Gullet Depth & $11 \mathrm{~mm}$ \\
\hline 3 & Pitch (Tooth spacing) & $58 \mathrm{~mm}$ \\
\hline 4 & Diameter Of Wheel & $962 \mathrm{~mm}$ \\
\hline 5 & Width of Wheel & $100 \mathrm{~mm}$ \\
\hline 6 & Blade length & $10 \mathrm{~m}$ \\
\hline 7 & Length of Carriage & 4900 \\
\hline 8 & Carriage width & $1900 \mathrm{~mm}$ \\
\hline 9 & Length of lumber & $3470 \mathrm{~mm}$ \\
\hline 10 & Thickness of lumber & $26 \mathrm{~mm}$ \\
\hline
\end{tabular}

Table 2. Measured Data of the Band Mill

\subsection{Data Collection}

Within the framework of this study, 10 Gmelina logs were sawed. The technique used was complete live sawing method. Boards with a thickness of $25.4 \mathrm{~mm}$ were produced. Processing operations were measured in 
seconds with the use of a stopwatch and the cumulative time was recorded after each completed log sawing process. The duration of each individual operation was determined by calculating the difference between two cumulative times. The duration of the following operations was measured: The field study was conducted in between April and December 2018.

\begin{tabular}{|l|c|}
\hline \multicolumn{1}{|c|}{ Work Elements } & $\begin{array}{c}\text { Time } \\
\text { Taken }\end{array}$ \\
\hline $\begin{array}{l}\text { Loading the log on the fixed carriage } \\
\text { on the rail }\end{array}$ & $\mathrm{t}_{1}$ \\
\hline $\begin{array}{l}\text { Moving the headrig (bandmill) and } \\
\text { engaging it with the log on the rail }\end{array}$ & $\mathrm{t}_{2}$ \\
\hline $\begin{array}{l}\text { Sawing by through and through } \\
\text { method }\end{array}$ & $\mathrm{t}_{3}$ \\
\hline $\begin{array}{l}\text { Drawing the headrig away and } \\
\text { returning it to the start position }\end{array}$ & $\mathrm{t}_{4}$ \\
\hline Removing the slab and lumbers & $\mathrm{t}_{5}$ \\
\hline Releasing the last sawn-board & $\mathrm{t}_{6}$ \\
\hline $\begin{array}{l}\text { Time of returning the headrig to the } \\
\text { start position after the final sawing }\end{array}$ & $\mathrm{t}_{7}$ \\
\hline
\end{tabular}

Table 3. Work and Time Elements of the Band mill

\subsection{Production Estimation Parameters}

Production estimation was expressed in terms of machine time, productivity and time study methods. Machine time is further broken into scheduled operations and non-scheduled operations. The scheduled operations were productive and non-productive. The non-productive operations are mostly associated with delays. The concepts of productivity and time study are expressed as shown in Table 4.

The SMH is the total time the machine is scheduled to work while the $\mathrm{PMH}$ represents the time during which the machine actually performs the work. The PMH excludes all the delays. Machine availability represents the percentage of the scheduled time in which the machine is mechanically able to perform work. Machine utilisation measures the percentage of scheduled time that the machine is actually productive. Machine productivity is defined as production per unit time, it is measured as the capacity of the log band saw and was calculated for each sawing based on the log volume and the time required for its processing according to equation (7).

\begin{tabular}{|c|c|c|c|}
\hline Concept & Acronym & \multicolumn{2}{|l|}{ Related Equation } \\
\hline Scheduled Machine Hours & $\mathrm{SMH}$ & $\begin{array}{l}S M H=P M H+D E L A Y S \\
S M H=P M H+H_{m e c h}+H_{o p}+H_{o t h}\end{array}$ & $\begin{array}{l}(1) \\
(2)\end{array}$ \\
\hline Productive machine Hours & $\mathrm{PMH}$ & $P M H=S M H-D E L A Y S$ & (3) \\
\hline Machine Availability & MA & $M A=\frac{\text { SMH-Mechanical Delays }}{S M H} \times 100$ & $(4)$ \\
\hline Machine Utilisation & MUT & $\begin{array}{c}M U T=\frac{\mathrm{PMH}}{\mathrm{SMH}} \times 100 \\
=\frac{\mathrm{PMH}}{\mathrm{SMH}}=\frac{\mathrm{SMH}-\mathrm{SMH}\left(\frac{\mathrm{MechD}+\mathrm{OpD}+\mathrm{OthD}}{100}\right)}{\mathrm{SMH}}\end{array}$ & $\begin{array}{l}(5) \\
(6)\end{array}$ \\
\hline Machine Productivity & $\begin{array}{l}\text { C } \\
\text { (Capacity) }\end{array}$ & Machine Productivity $=\frac{\text { Volume }}{P M H}$ or $\frac{\text { Volume }}{S M H}$ & $(7)$ \\
\hline Delay & Delay & Delay $=H_{\text {mech }}+H_{o p}+H_{o t h}$ & $(8)$ \\
\hline $\begin{array}{l}\text { Mechanical Delay } \\
\text { Operation Delay } \\
\text { Other Delay }\end{array}$ & $\begin{array}{l}\text { MechD } \\
\text { OpD } \\
\text { OthD }\end{array}$ & $\begin{array}{l}\text { MechD }=\frac{H_{\text {mech }}}{S M H} \\
O p D=\frac{H_{\text {op }}}{S M H} \\
\text { OthD }=\frac{H_{\text {oth }}}{S M H}\end{array}$ & $\begin{array}{l}(9) \\
(10) \\
(11) \\
\end{array}$ \\
\hline Delay Factor & $\mathrm{DF}_{\text {tot }}$ & $D F_{\text {tot }}=D F_{\text {mech }}+D F_{o p}+D F_{o t h}$ & (12) \\
\hline
\end{tabular}

Table 4. Concepts of Productivity and Time Study

\subsection{Delay Parameters}

Delays are recognized as being one of the major factors that limit productivity in most operations and are, therefore, an integral part of most time studies. But, delay events are erratic in both occurrence and magnitude and are, therefore, difficult to precisely quantify within the relatively short observation period of a typical time and motion [16] study. Thus, delay information from individual studies has limited transferability. Research on the productivity of forest operations is obtained by measuring the time consumed and the quantity produced and then carrying out a statistical evaluation to relate the two quantities [17].

Ten complete time studies which were recorded on sawmills within April, 2018, were used for the analyses of delays. All of the time studies were set up and carried out by the same principal investigator and with the same methods.
All of the time studies used three clearly defined delay types:

1. mechanical delays (breakdowns, saw-blade derail, saw blade replacement, tensioning); which can be termed as unavoidable delays

2. operator delays (physiological, rest, break, phone call), and

3. Other delays (including waiting, interference, reconnaissance, refuel, preparation).

Delays caused by the study itself, including giving instructions and measuring logs, have all been excluded. Delays for the main meal (if the operator took any) and relocation to and from site are also not included in the data sets. All other delays are included. In most published reports, delays are reported as a percentage of the total scheduled time. Assuming just three delay categories, SMH can be calculated by Equation [1]. Normally delays are presented as a percentage of SMH. 
Mechanical delays (MechD), for example, can be expressed by

MechD = mechanical delay $(\%)$

Expressed in terms of utilization (\%), we can derive Equation (2) that separates the three delay percentages. The last line rearranges the Equation to isolate mechanical delay.

Equation (2) shows that mechanical delays become a function that is also dependent on operator and other delays. This assumes a level of dependence between the delay types.

In equation 8, the total delay factor is just the summation of the three individual delay factors and the conversion of $\mathrm{PMH}$ into $\mathrm{SMH}$ is given in Equation (3).

\subsection{Data Analysis}

The time taken to process each individual log was recorded using an electronic stopwatch and entered into pre-printed data sheets. Productive time was separated from delay time and split into factor and functional elements. Delay time was also split into the three conventional groups known as mechanical, operator and other delay factors. The total processing time was determined from the measured results. The time and share of each partial operations during the sawing process were also determined as well as their function influence on the capacity of the log band saw. The data were analysed using descriptive statistics and ANOVA.

\section{RESULTS AND DISCUSSION}

The parameters of sawed logs and the operation time, including; loading and offloading times, are shown using descriptive statistics in Table 5. The information presented in Table 5 showed that most time was spent on the actual log sawing process, taking about $56 \%$ of the total operation period. Figure 3 showed all the observed times according to the operations. Unavoidable manipulation such as returning the head rig, setting the head rig to the next board thickness and drawing the log away from the saw also takes a lot of time in the process. The results showed a concurrent increase in the operational time required as the logs' parameters (lengths, diameter and invariably volume) increased. The relationship between operation times and diameters of sawed logs is presented in Figure 4.

\begin{tabular}{|l|c|c|c|c|}
\hline Parameter & Minimum & Maximum & Median & Mean \\
\hline Log length, $\mathrm{m}$ & 2.84 & 3.78 & 3.2 & $3.1 \pm 0.4$ \\
\hline Mid diameter, $\mathrm{m}$ & 0.4 & 0.6 & 0.5 & $0.5 \pm 0.02$ \\
\hline Log volume, $\mathrm{m}^{3}$ & 0.31 & 0.47 & 0.39 & $0.38 \pm 0.04$ \\
\hline Time of loading the log on carriage $\left(\mathrm{t}_{1}\right), \mathrm{s}$ & 6 & 52 & 30 & $32 \pm 4.20$ \\
\hline $\begin{array}{l}\text { Time for setting the sawing position and engaging the } \\
\text { headrig with the log on the rail }\left(\mathrm{t}_{2}\right), \mathrm{s}\end{array}$ & 20 & 100 & 66 & $67.1 \pm 8.1$ \\
\hline Sawing time $\left(\mathrm{t}_{3}\right), \mathrm{s}$ & 85 & 92 & 86 & $88 \pm 9.3$ \\
\hline $\begin{array}{l}\text { Time for drawing the headrig away and returning it to } \\
\text { the start position }\left(\mathrm{t}_{4}\right), \mathrm{s}\end{array}$ & 15 & 121 & 64 & $63 \pm 7.7$ \\
\hline Time of slab and board removal $\left(\mathrm{t}_{5}\right), \mathrm{s}$ & 14 & 24 & 14 & $15 \pm 4.2$ \\
\hline Time for releasing the last sawn-board $\left(\mathrm{t}_{6}\right), \mathrm{s}$ & 4 & 8 & 6 & $5 \pm 2.2$ \\
\hline $\begin{array}{l}\text { Time of returning the headrig to the start position after } \\
\text { the final sawing }\left(\mathrm{t}_{7}\right), \mathrm{s}\end{array}$ & 8 & 60 & 15 & $13 \pm 3.5$ \\
\hline $\begin{array}{l}\text { Time required for a complete sawing cycle }(\text { sawing and } \\
\text { manipulation) }\left(\mathrm{t}_{8}\right), \mathrm{s}\end{array}$ & 152 & 457 & 281 & $288 \pm 14.2$ \\
\hline Time required for manipulation $\left(\mathrm{t}_{9}\right), \mathrm{s}$ & 47 & 289 & 151 & $149 \pm 18.2$ \\
\hline The share of manipulation in total time, $\%$ & 31 & 63 & 54 & $0.51 \pm 0.16$ \\
\hline Log band saw capacity, $\mathrm{m}^{3} / \mathrm{h}$ & 7.44 & 3.71 & 5.03 & $5.4 \pm 2.2$ \\
\hline
\end{tabular}

Table 5. Descriptive Statistics of Dimensions for Sawed Logs, Operation Time and Capacity

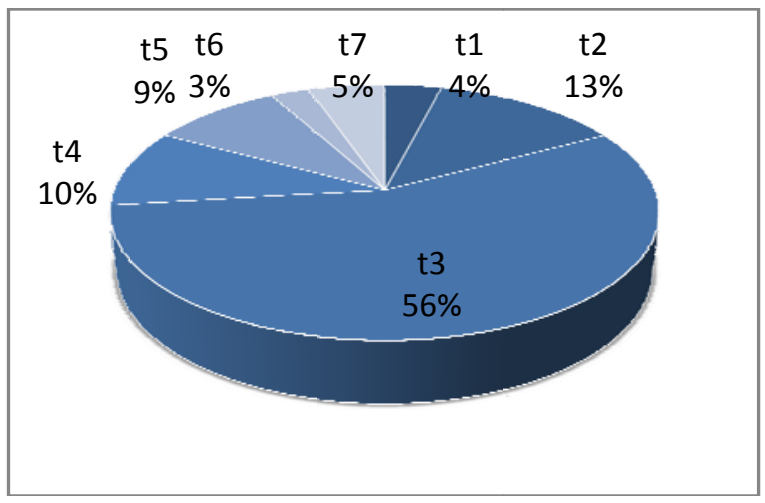

Fig. 3. Distribution of percentage of work-time for sawing operations

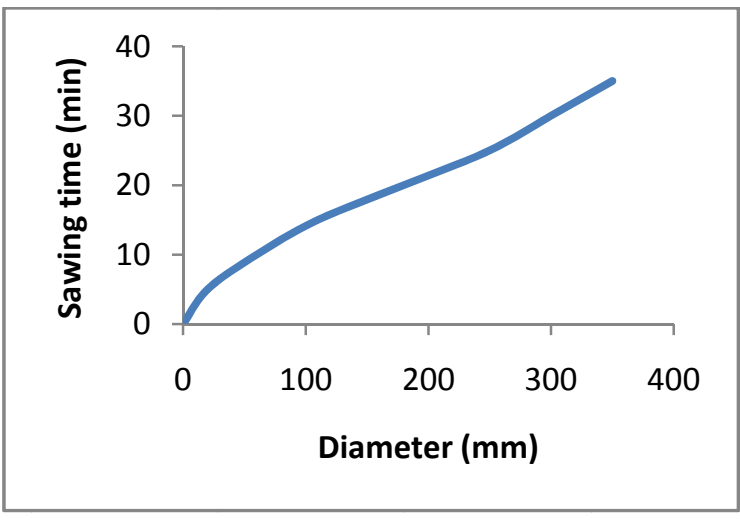

Fig. 4. Effects of log diameter on sawing time per cycle 


\begin{tabular}{|c|c|c|c|}
\hline S/No & $\begin{array}{l}\text { Type of } \\
\text { Delay }\end{array}$ & $\begin{array}{c}\text { Time } \\
\text { (1000sec) }\end{array}$ & $\begin{array}{c}\text { Percentage } \\
(\%)\end{array}$ \\
\hline 1 & $\begin{array}{l}\text { Mechanical } \\
\text { Delay }\end{array}$ & 51 & 59 \\
\hline 2 & $\begin{array}{l}\text { Operators } \\
\text { Delay }\end{array}$ & 22 & 26 \\
\hline 3 & $\begin{array}{l}\text { Other } \\
\text { Delays }\end{array}$ & 13 & 15 \\
\hline
\end{tabular}

Table 6. Delay Parameters in Percentage

\subsection{Delay}

The reason why so much time is required for manipulation in the sawing process lies in removal and transportation of slabs when starting sawing of logs as well as problems with transportation of boards. The slowness of workers that arrange the boards also contribute to slower manipulation. The operation time required for loading the $\log$ on the rail and setting the sawing position that can be shortened by training the machine operator to quickly and precisely load the log for the first cut and reset the head rig position after each cut.

Based on dependencies of the log band saw on diameter, length and volume of the processed logs, the most influential factor is the volume of the log being processed, and the least influential is the length of the $\log$. The experiment conducted shows that the log feed speed is reduced with the increase in log diameter. And increase in log diameter results in greater use of sawing energy. Greater log feed speed results in the increased capacity of the log band saw. However, this applies to equal diameter of processed logs.

Sawing time per log was significantly affected by diameter at top, middle and base as shown in Fig. 4. Total Sawing time is extended with the increase in log diameter due to longer time required for the actual sawing caused by a larger number of boards i.e. saw kerfs, this corroborates the findings of Istvanic et al [18].

These delay factor representations are used throughout the analyses and results. Operator year of experience was 10 years and age was 39 .

$W=$ productivity; $V=$ Volume of $\log$ sawn in a time unit $T U=$ time unit taken into consideration

(13)

$$
\mathrm{W}=\frac{V}{T U}
$$

$\mathrm{W}=$ productivity

$\mathrm{V}=$ Volume of log sawn in a time unit $=5.4 \mathrm{~m}^{3}$

$\mathrm{TU}=$ time unit taken into consideration $=25270 \mathrm{sec}$

$\sum$ Other delay $(\mathrm{s})=1166$

$\sum$ operator delay $(\mathrm{s})=2074$

$\sum$ mechanical delay $(\mathrm{s})=3890$

$\sum$ productive time $(\mathrm{PMH})(\mathrm{s})=25270$

$\mathrm{SMH}=\mathrm{PMH}+\mathrm{Hmech}+$ Hop + Hoth $=$

$$
=25270+3890+2074+1166=32400
$$

$\mathrm{SMH}=32400$ secs (9hours)

Scheduled Machine Hours (s) = 32400 (9hrs)

Mechanical delay $(\%)=\frac{3890}{32400} \times 100$

$$
=12.01 \%
$$

Utilization $(\%)=\frac{P M H}{S M H} X 100=\frac{25270}{32400} \times 100$

$$
\begin{gathered}
=77.99 \% \\
\text { DFtot }=\text { DFmech }+ \text { DFop + DFoth } \\
=3890+2074+1166=7130 \mathrm{~s} \\
\mathrm{~W}=\frac{V}{T U}=\frac{5.4}{9}=0.6 \mathrm{~m}^{3} / \mathrm{hr}
\end{gathered}
$$

- Productive time $\square$ Mechanical delay

Operation delay Other delay

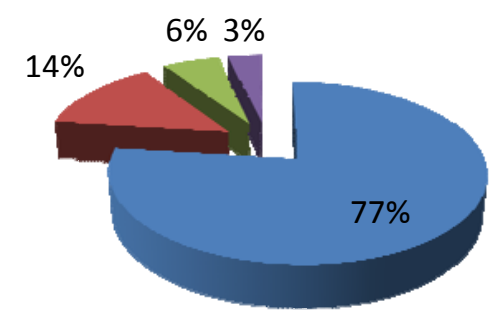

Fig. 5. Proportion of delays associated with the sawmilling

The result shows that the percentage of utilization of the machine was $77.99 \%$. The percentage of the total delay was $22.01 \%$ which comprise of mechanical delay, other delay and operational delay. The mechanical delay has over $50 \%$ of the total delay which affect the productivity, this corroborates the report of Ghaffarinyan et al [19].

\section{CONCLUSION}

The research shows that the delay still affect the productivity of the sawing process. The greatest share in manipulation time takes place during setting the saw position, moving the head rig with the saw blade to engage log for cutting, and withdrawing the head rig to the original position. The log volume, whose increase also increases the capacity of the band, has the most significant effect on $\log$ band saw capacity. It is therefore imperative to take into account the volume of logs being processed when calculating the norms and monitoring the work of the operator. Saw capacity may be increased by reducing the share of manipulating time in the total time of sawing process. The time required for setting the saw position, moving the head rig to the log may be reduced by additional training of the operator at the control panel. Relevant and valuable production and delay data help to improve and maintain more efficient production lines and also to efficiently monitor and optimize available resources in order to reduce wastage and increase production yield. Based on this classification, the mill in consideration is a small level sawmill. Results of production estimate are increasingly used for management decisions such as aiding in setting productivity targets, assessing payment schedules, optimizing systems, and selecting among alternative machine choices. Published time and motion studies have shown that while it is possible to accurately capture and analyze work time related aspects of an operation, it is difficult to accurately assess delay information. 


\section{RESEARCH LIMITATION}

The research is limited to logs of particular dimension, quality and boards. Through and through methods of sawing was the process of conversion employed.

\section{REFERENCES}

[1] Dozzi S.P., and AbouRizk S.M.: (1993). Productivity in Construction. Institute for Research in Construction, National Research Council, Ottawa, Ontario, 1993.

[2] Wang J., Long J., McNeel J., Baumgras J.: Productivity and cost of manual felling and cable skidding in central Appalachian hardwood forests. Forest Product Journal 54, 45-51, 2004.

[3] Ojo S.O., and Obabokun M.: Analyses of Productivity and Technical Efficiency of Sawmill Industries in Nigeria. Journal of Tropical Forest Science, 17, 428-437, 2005.

[4] Ghaffarinyan M.R., and Acuna M.: Productivity of Road Side Processing System in Western Australlia. Silva Balcanica, 13, 49-60, 2012.

[5] Silayo, D.S.A., and Migunga, G.A.: Productivity and Cost Modeling for Tree Harvesting Operations Using Chainsaw in Plantation Forest, Tanzania. International Journal of Engineering and Technology, 3, 464-472, 2014.

[6] Aune, J.E.: System Simulation - A technique for Sawmill Productivity Analyses and Designs. The Forestry Chronicle, 66-69, 1974.

[7] Brinker, R.W., Miller, D., Stokes, B.J., and Lanford, B.L.: 1989. Machine rates for selected forest harvesting machines. Circular 296, Alabama Agric. Exp. Station, Auburn Univ. 24p, 1989.

[8] LeDoux, C.B. and Huyler, N.K.: Cost comparison for three harvesting systems operating in northern hardwood stands. Res. Paper NE-715. USDA, Forest Service, Northeastern Res. Station, Newtown Square, PA, 4 p, 2000

[9] Ghaffarinyan M.R., Sobhani H.: Cost production study of motor-manually felling and processing of logs, Forest Science 3, 69-76, 2007.

[10]Rafaelle, S. and Rien, V.: Analyzing and Estimating Delays in Harvester Operations, International Journal of Forest Engineering 19, 3641, 2008.

[11]Behjou, F.K., Majnounian B. Deorak J., Namianian M., Saeed A., and Feghhi J.: Productivity and Cost of Manual Felling with a Chainsaw in Caspian Forests. Journal of Forest Science, 55, 96-100, 2009.

[12] Azarnoush M.R., Fathi J.: Efficiency economic of chainsaw and Timber Jack 450C Skidder evaluation in felling operation and ground-based skidding system, Journal of Advances in Biology, 4, 461-476, 2014.

[13] Subramaniam S.K., and Husin S.: Machine Efficiency and Man Power Utilization in Production Lines. 8th bWSEAS International Conference (pp. 70- 75). Melaka Malaysia:
WSEAS Publishers, 2014.

[14] Amanparteek Singh., and Jag Singh.: Identification and Analysis of Various Delays Affecting Machine Utilization in a Tractor Part Industry Using Work Sampling Techniques. Indian Journal of Science and Technology, 9, 1-5, 2016.

[15] McEwan A., Brink M. and Spinelli R.: Factors Affecting the Productivity and Work Quality of Chain Flain Delimbing and Debarking. Silva Fennica, 51, 1-14, 2017.

[16]Björheden, R., Apel, K., Shiba, M., and Thompson, M.A.: IUFRO Forest work study nomenclature, Swedish Univ. of Agricultural Science, Dept. of Operational Efficiency, Garpenberg. 16 p, 1995.

[17] Proto, A.R., Sperandio, G., Costa, C., Maesano, M., Antonnucci, F., Macri, G., Mugnozza, G.S., and Zinbalatti, G.: A Three-Step Neural Network Artificial Intelligence Modeling Approach for Time, Productivity and Costs Prediction: A Case Study in Italian Forestry, Croatian Journal for Engineers, 41, 35-47, 2020.

[18] Istvanic, J., Lucic, R.B., Jug, M., and Karan, R.: Analysis of Factors Affecting Log Band Saw Capacity, Croatian Journal for Engineers 30, 27 $35,2009$.

[19] Ghaffarinyan M.R., Naghdi R., Ghajar I., Nikooy M.: Time prediction models and cost evaluation of cut-to-length (CTL) harvesting method in a mountainous forest. Small-scale Forestry 12, 181192, 2012.

https://doi.org/10.1007/s11842-012-9204-4

Authors: Temidayo E Omoniyi, PhD. Professor Musiliu A. Onilude, PhD. University of Ibadan, Faculty of Technology, Department of Wood Products Engineering, 200284, Ibadan, Nigeria. Phone: $+2348037881122$

E-mail: temidayoomoniyi@gmail.com, profonilude@gmail.com 